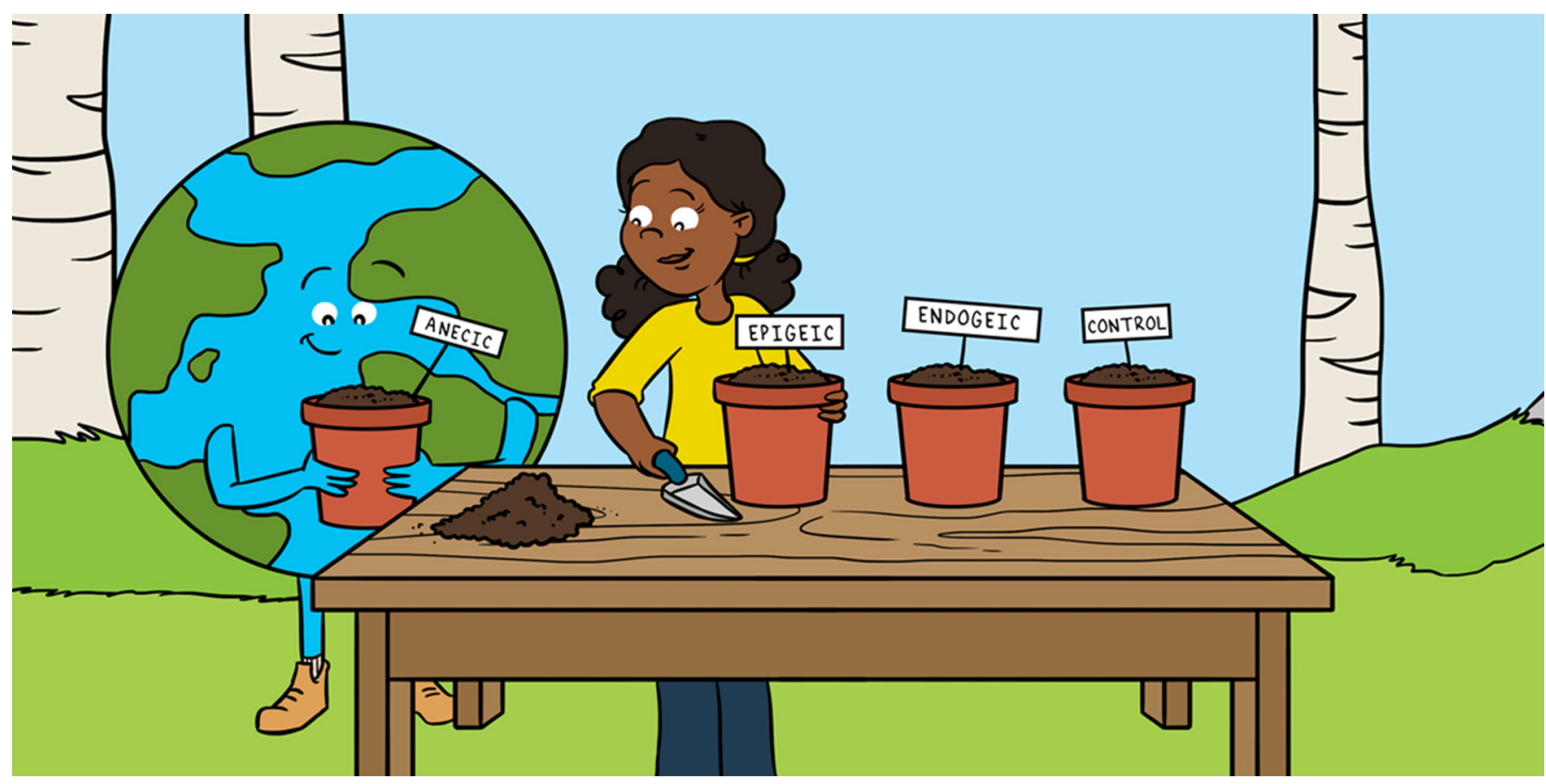

\title{
EARTHWORMS AND THEIR ROLE IN GREENHOUSE GAS EMISSIONS
}

\author{
Pierre Ganault $^{1 *}$, Sacha Delmotte ${ }^{2}$, Agnès Duhamet ${ }^{2}$, Gaëlle Lextrait $^{2}$ and Yvan Capowiez $^{3}$ \\ ${ }^{1}$ CEFE, CNRS, EPHE, IRD, Université de Montpellier, Université Paul-Valéry Montpellier, Montpellier, France \\ ${ }^{2}$ Biology and Ecology Departement, Université de Montpellier, Montpellier, France \\ ${ }^{3}$ INRAE, UMR 1114 EMMAH, INRAE/Université d'Avignon, Avignon, France
}

YOUNG REVIEWER:

GWEN

AGE: 13
The mass of all earthworms living on our planet is greater than the mass of any other terrestrial animal species. There are over 7,000 species of earthworms, and they are involved in many processes that keep soils healthy and help plants to grow, which makes them extremely important organisms to study. The activity of earthworms also stimulates the growth of bacteria, both in the soil and in their guts. Some studies have suggested that these bacteria might increase greenhouse gas emissions, particularly the gases carbon dioxide and nitrous oxide that contribute to global warming. So, are earthworms good or bad for the environment, overall? This article will describe the experiments that can be used to study the links between earthworms and greenhouse gas production, as well as the limitations of these experiments. The effects of earthworms on soil processes are very complex and therefore scientifically challenging, important, and exciting. 
Figure 1

(A) The three main groups of earthworms, epigeic, anecic, and endogeic. Illustration credits:

www.lesbullesdemo.fr. (B) $X$-ray $3 D$

reconstruction of the burrow systems of one endogeic species called gray worm (Aporrectodea icterica) and one anecic species called nightcrawler (Lumbricus terrestris). $X$-ray image credits: Yvan Capowiez.

\section{ECOLOGICAL GROUP}

Earthworms differ regarding where they live in the soil, what they eat, and what color is their skin. There are three main groups: epigeics (pronounced "ep-i-jEE-ik"), endogeic (pronounced "en-d-oh-jEE-ik"), and anecic earthworms (pronounced "an-e-c-ik").

\section{ORGANIC MATTER}

It is matter composed of organic compounds that comes from the remains of organisms, such as plants and animals and their waste products in

the environment.

\section{CASTS}

It is earthworm poo. Depending on the earthworm ecological group, they can be deposited at the soil surface or within the soil, in their burrow.

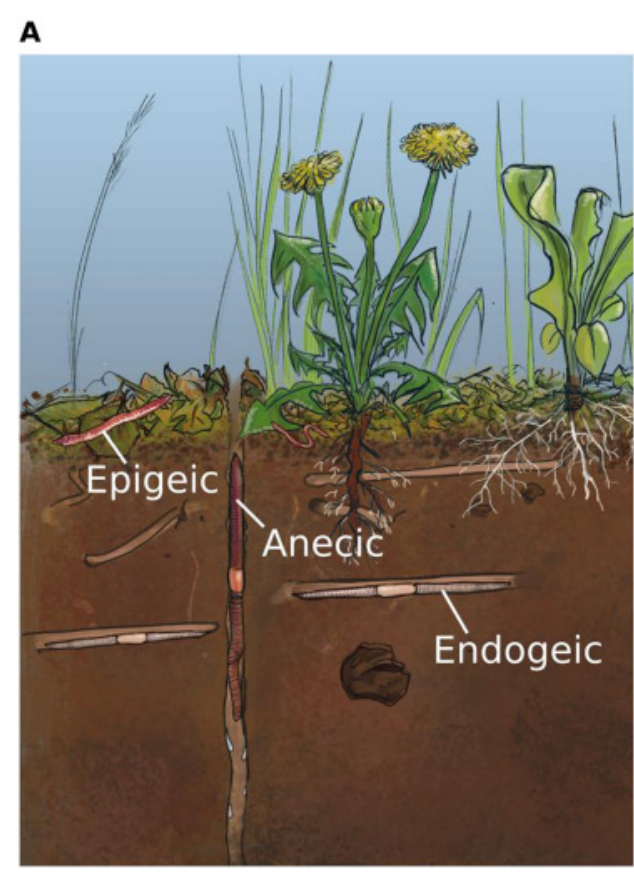

B Endogeic earthworm

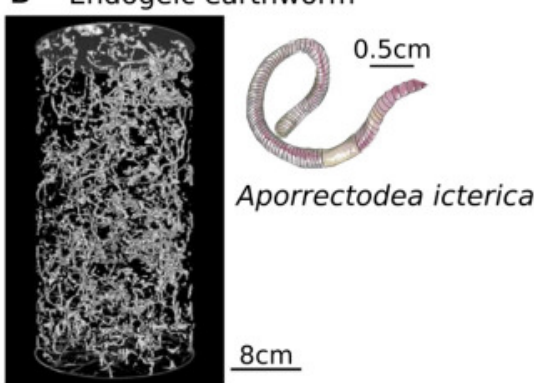

Anecic earthworm

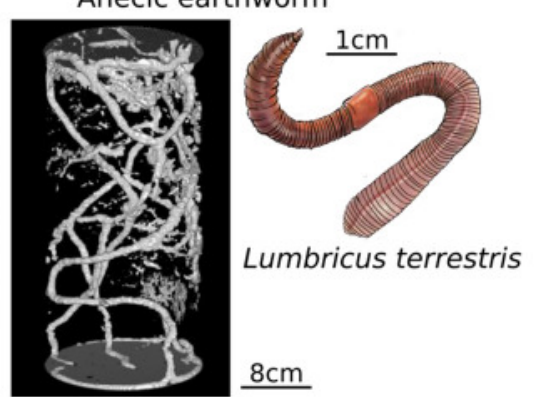

Figure 1

\section{EARTHWORMS, THE UNDERGROUND ENGINEERS}

Under our feet, thousands of animals live in the soil, including the famous earthworms. The term "earthworms" actually refers to many species. Scientists have described around 7,000 earthworm species worldwide, but some areas are poorly studied, and scientists expect that there are more than 30,000 earthworm species yet to be described [1]. Earthworms are invertebrates, so they do not have bones. Unlike insects, earthworms also lack an external skeleton and they do not have eyes, but they have strong muscles. Earthworms can move through the soil, and even eat it, along with some dead leaves. Although most earthworm species look fairly similar, they have various lifestyles, which fall into three main ecological groups (Figure 1A) [2].

The first group, called epigeics, are small earthworms $(3-10 \mathrm{~cm})$ with a red color, and can be used in vermicomposting. Epigeic earthworms live in dead leaves. Their color protects them from UV radiation and camouflages them from surface predators. Without digging into the soil, they eat dead leaves and transform them into small pieces of organic matter in their feces, which are called casts. Endogeic earthworms are larger $(5-15 \mathrm{~cm})$ and completely unpigmented. They only live in soils and create numerous burrows (Figure 1B). In an experimental pot, four endogeic earthworms dug $2.2 \mathrm{~km}$ of burrows of $3.5 \mathrm{~mm}$ width per cubic meter of soil in only 6 weeks [3]! As they dig, they also eat many very small pieces of dead leaves that are in the soil, and they mix organic matter within the soil (Figure 2). The third group is called anecic earthworms. They are the largest, they can 
Figure 2

Organic matter passes through the earthworm's digestive tract, is broken into smaller pieces, digested, and the remainder exits as feces called casts. Casts then help to feed bacteria. Bacteria are also present within the digestive tract of earthworms. Bacteria need the right mix of organic matter, water, and air to be active. Image inspired by Drake and Horn [4].

\section{ECOSYSTEM \\ ENGINEER}

They are organisms that modulate the availability of resources to other species. Termites, ants, and earthworms are the major ecosystem engineers.

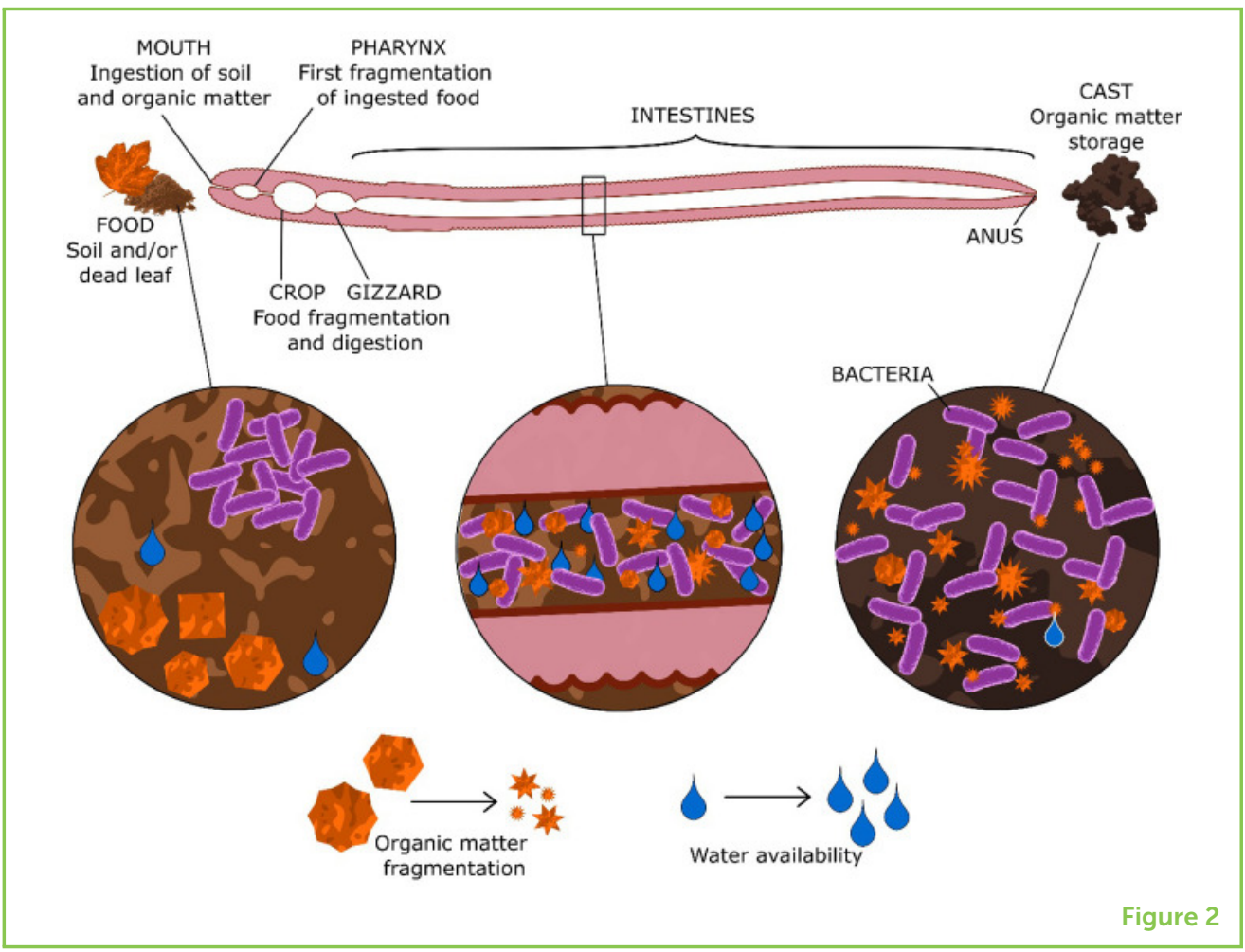

grow as big as $10 \mathrm{~cm}$ and up to $1 \mathrm{~m}$ ! They dig deep vertical burrows (Figure 1), that can exceed 1 meter in depth. During the night, they stick their heads out to grab dead leaves on the surface and bring them to deeper soil layers. Since only their heads leave the soil, only their heads are pigmented.

Eating or burying dead leaves and moving through the soil by creating burrows are the two main actions of earthworms. These actions are good for the soil, the other soil organisms, and the entire ecosystem, which has earned earthworms the name "ecosystem engineers."

\section{HOW EARTHWORMS ARE CHANGING THE SOIL AND GROWING BACTERIA}

Earthworm burrows profoundly change soil structure by creating large spaces in the compact soil. The burrows are the habitat of many organisms like small invertebrates, bacteria, and plant roots. Burrows also act as pipes that increase water and oxygen flow between the surface and deeper soil layers. Earthworms of different ecological group build burrows that affect water and gas fluxes differently. In the experiment of Capowiez et al. [3], done in PVC tube $(16 \mathrm{~cm}$ diameter, $30 \mathrm{~cm}$ height, Figure 1B), the endogeic earthworms' burrows allowed a water infiltration rate of $5.2 \mathrm{~L}$ per minute, while this rate reached $12.4 \mathrm{~L}$ per minute in the anecic earthworm' burrows as they are larger, more continuous, and vertical. 


\section{OXYGEN}

This is a gas constituting $21 \%$ of the air we breathe. Plants produce oxygen from carbon dioxide, water and sunlight while animals use oxygen and produce carbon dioxide.

\section{CARBON DIOXIDE}

It is a colorless gas composed of one atom of carbon and two of oxygen. Its atmospheric concentration raised from 0.028 to $0.042 \%$ since 1850 causing an increase of $1^{\circ}$ of global temperature.

\section{NITROUS OXIDE}

It is a colorless gas composed of two atom of nitrogen and one of oxygen. It is in very low concentration but one nitrous oxide molecule warms the atmosphere as 270 carbon dioxide molecules.

\section{GREENHOUSE}

\section{GASES}

It is a gas that absorbs and emits solar energy causing the greenhouse effect, i.e., warming the atmosphere.

In ecosystems where earthworms are abundant, dead leaves disappear quite quickly and do not accumulate on the soil surface. Epigeic earthworms transform dead leaves into smaller pieces repacked in their casts and anecic earthworms bury dead leaves in deeper soil layers. Endogeic earthworms then eat small dead leaves or root particles along with the soil and excrete it behind them wherever they go. These actions of earthworms result in the redistribution of organic matter throughout the soil. Instead of accumulating at the soil surface, the organic matter is more spread out and available for plant roots and other soil inhabitants.

The changes of the soil made by earthworms affect another important group of soil organisms, like bacteria. Bacteria need the right balance of food, water, and air to live. They transform the small pieces of organic matter into even smaller particles, breaking them down into carbon and nitrogen. These particles are so small that plant roots can easily absorb them and use them to grow. To break down their food, bacteria use oxygen (they breath, even without having lungs) and produce carbon dioxide as a waste product. If there is too much water around, such as during a flood or in rice fields, the bacteria instead produce nitrous oxide as a waste product. Carbon dioxide and nitrous oxide are greenhouse gases that increase the atmosphere's temperature, so contributing to climate change.

In some soils, bacteria may lack organic matter, air, or water, and be less active. Earthworms can "wake up" bacteria by making organic matter, water, and air more available. This effect is even stronger for the bacteria living in the earthworm's gut (Figure 2). In the gut, organic matter and soil are perfectly mixed in an environment saturated with water. This is heaven for bacteria that produce nitrous oxide [4]. Since earthworms stimulate bacteria that produce carbon dioxide and nitrous oxide, this makes us wonder if earthworms serve to increase or decrease greenhouse gases emissions.

\section{STUDYING THE IMPACT OF EARTHWORMS ON GREENHOUSE GASES EMISSIONS}

To study how earthworms affect bacteria and the greenhouse gases they produce, scientists can run experiments. In one type of laboratory experiment, scientists use pots filled with soil that is sifted to remove rocks, all animals, and roots. Then earthworms are added, usually a few individuals of the same species, ideally in numbers close to what would be found in nature. Some pots are kept without earthworms, for comparison. Then, greenhouse gases emissions are measured the soil surface and the bacteria in the pots are studied, to see whether greenhouse gases emissions are higher in the presence or absence of earthworms. 
Figure 3

(A) An experimental chamber can be used to measure GHG emissions in natural environments. Gases produced by bacteria accumulate in the sealed chamber, and then are sampled with a syringe through the latex plug to measure the levels of carbon dioxide $\left(\mathrm{CO}_{2}\right)$ and nitrous oxide $\left(\mathrm{NO}_{2}\right)$. (B) Example of a chamber placed on the soil surface of an experimental pot with earthworm and plants. Credits: Pierre Ganault.

$\mathrm{pH}$

In chemistry, $\mathrm{pH}$ is a scale used to specify the acidity or basicity of an liquid solution. Acidic solutions are measured to have lower $\mathrm{pH}$ values than basic or alkaline solutions.
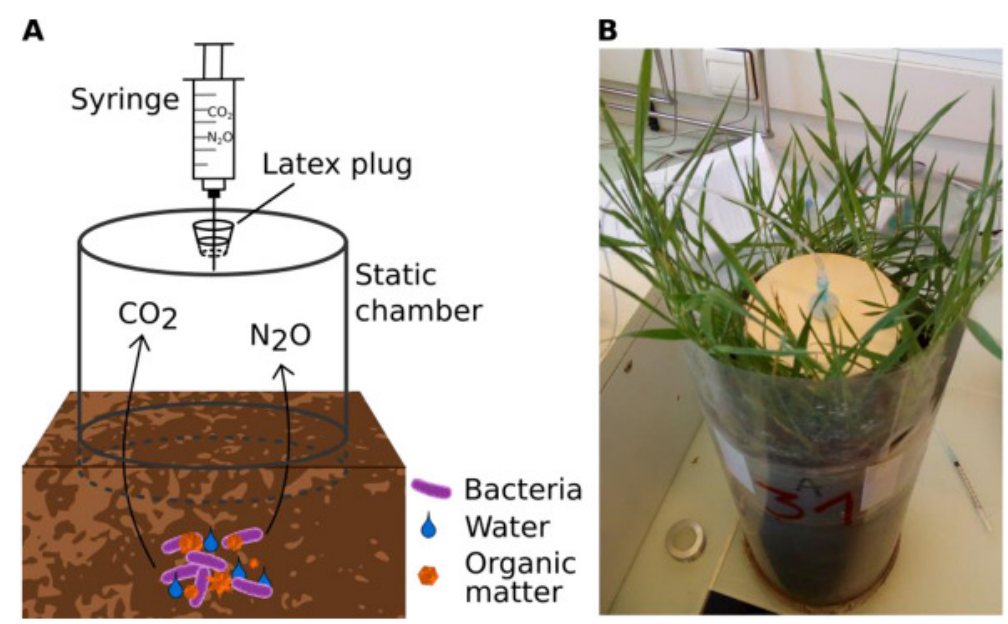

Figure 3

Another method scientists use is to measure greenhouse gases in nature. In this case, cylindrical chambers are pushed into the ground to measure gases like carbon dioxide and nitrous oxide (Figure 3). The earthworms in the soil are also studied so that scientists can try to relate greenhouse gases emissions to the abundance and number of species of earthworms present. Scientists can also measure other soil characteristics important for bacterial activity, including water content, availability of organic matter, and $\mathbf{p H}$.

Another way to know the effect of earthworms on greenhouse gases emissions is to gather information from all the existing studies. So, it was found that, on average, earthworms increase carbon dioxide emissions by $33 \%$ and nitrous oxide emissions by $42 \%$ [5]. This seems to tell us that, although they are beneficial for soil health, earthworms may be detrimental for the environment because they increase bacterial activity and related greenhouse emissions.

\section{THESE EXPERIMENTS HAVE LIMITS}

This seems like a real dilemma: earthworms improve soil health, but at the same time they appear to increase greenhouse gases emissions! Before we draw this conclusion, however, it is important to recognize that the experiments we have described all have drawbacks that make it difficult to be completely certain of the role earthworms play in greenhouse gases emissions. The interactions between earthworms, bacteria, soil, plants, and water that result in greenhouse gases emissions are extremely complex. These factors vary tremendously in the natural environment and are very difficult to recreate accurately in scientific experiments.

The first important factor limiting our full understanding of the role of earthworms in greenhouse gases emissions is the great diversity 
of soil properties, such as sand content. Most earthworms generally prefer soils with a low sand content because sandy soils dry faster, and sand particles can be abrasive for their skin. Soil pH can also strongly affect earthworms, and many may not survive in soils with a $\mathrm{pH}$ below 4.5. It would be extremely difficult to make experimental pots for the thousands of different soil types that exist in nature, so our knowledge is currently limited to certain common types of soil.

A second limitation is that very few studies included plants in the experiments. Plants absorb water and nutrients with their roots, reducing the availability of water and nutrients for earthworms and bacteria. However, plants and bacteria also help each other. Plant roots produce sugar in the surrounding soil that bacteria can eat in exchange for providing minerals that plants need. Unfortunately, it is very difficult to set up an experiment that could test all the possible positive and negative interactions happening at the same time in the soil.

The third limitation is that most studies kept the soil water content constant. This is generally done to optimize earthworm activity. In nature, soils are constantly drying out and being remoistened by rainfall. Earthworms can be completely inactive if the soil gets too dry. This means that experiments in which the soil has a constant water content might overestimate the negative effects of earthworms on greenhouse gases emissions. In a lab experiment in which scientists used more realistic drying-rewetting cycles, the presence of earthworms actually reduced nitrous oxide emissions [6]. The scientists reasoned that earthworm burrows increased water flow to lower soil layers and aerated the soil, which sped up soil drying and reduced bacteria activity. The effects of drying-rewetting cycles are very important to study, especially since these cycles are expected to be more frequent and extreme with the on-going climate change.

\section{CLIMATE CHANGE-DO NOT BLAME THE EARTHWORMS}

We showed you just how complex it is to study greenhouse gases emissions from the soil. Earthworms modify the distribution of organic matter and the availability of water and air in the soil. All these change the activity of soil bacteria. However, soil bacteria also depend upon the properties of the soil, on drying-rewetting cycles, and on the plants that grow there. We are far from having enough studies with realistic experiments to understand the true role of earthworms in greenhouse gases emissions. On the other hand, human activities, notably agriculture, produce large amount of greenhouse gases and we need to keep thinking in innovative ways to improve the health of our planet and all living creatures. 


\section{ACKNOWLEDGMENTS}

The authors thank the young reviewer for his/her thorough work that improved the manuscript. The authors thank the TEBIS consortium and the different NGO, such as CARABES (https://assocarabes.com) with which the authors are working with to increase citizen awareness and encourage protection of soils and their biodiversity. The authors also thank Morgane Arietta Ganault (www.lesbullesdemo.fr) for the quality of the detailed drawings.

\section{REFERENCES}

1. Orgiazzi, A., Bardgett, R. D., Barrios, E., Behan-Pelletier, V., Briones, M. J. I., Chotte, J. L., et al. 2016. Global Soil Diversity Atlas. Luxembourg: European Union. Available online at: http://esdac.jrc.ec.europa.eu/public_path/ JRC_global_soilbio_atlas_online.pdf (accessed April 28, 2020).

2. Bottinelli, N., Hedde, M., Jouquet, P., and Capowiez, Y. 2020. An explicit definition of earthworm ecological categories - Marcel Bouché's triangle revisited. Geoderma 372:114361. doi: 10.1016/j.geoderma.2020.114361

3. Capowiez, Y., Bottinelli, N., Sammartino, S., Michel, E., and Jouquet, P. 2015. Morphological and functional characterisation of the burrow systems of six earthworm species (Lumbricidae). Biol. Fertil. Soils 51:869-77. doi: 10.1007/ s00374-015-1036-x

4. Drake, H. L., and Horn, M. A. 2006. Earthworms as a transient heaven for terrestrial denitrifying microbes: a review. Eng. Life Sci. 6:261-5. doi: 10.1002/elsc.200620126

5. Lubbers, I. M., van Groenigen, K. J., Fonte, S. J., Six, J., Brussaard, L., and van Groenigen, J. W. 2013. Greenhouse-gas emissions from soils increased by earthworms. Nat. Clim. Change 3:187-94. doi: 10.1038/nclimate1692

6. Chen, C., Whalen, J. K., and Guo, X. 2014. Earthworms reduce soil nitrous oxide emissions during drying and rewetting cycles. Soil Biol. Biochem. 68:117-24. doi: 10.1016/j.soilbio.2013.09.020

SUBMITTED: 15 May 2020; ACCEPTED: 06 April 2021; PUBLISHED ONLINE: 06 May 2021.

EDITED BY: Malte Jochum, German Centre for Integrative Biodiversity Research (iDiv), Germany

CITATION: Ganault P, Delmotte S, Duhamet A, Lextrait G and Capowiez Y (2021) Earthworms and Their Role in Greenhouse Gas Emissions. Front. Young Minds 9:562583. doi: 10.3389/frym.2021.562583

CONFLICT OF INTEREST: The authors declare that the research was conducted in the absence of any commercial or financial relationships that could be construed as a potential conflict of interest.

COPYRIGHT (c) 2021 Ganault, Delmotte, Duhamet, Lextrait and Capowiez. This is an open-access article distributed under the terms of the Creative Commons Attribution License (CC BY). The use, distribution or reproduction in other forums 

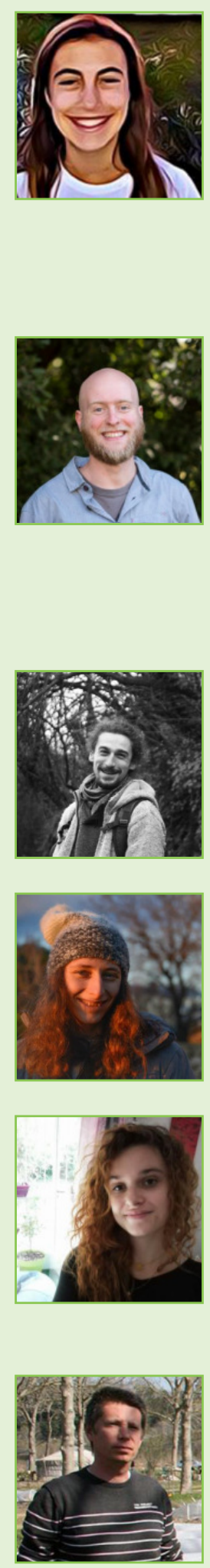

is permitted, provided the original author(s) and the copyright owner(s) are credited and that the original publication in this journal is cited, in accordance with accepted academic practice. No use, distribution or reproduction is permitted which does not comply with these terms.

\section{YOUNG REVIEWER}

\section{GWEN, AGE: 13}

$\mathrm{Hi}$, my name is Gwen, I live in the U.S. and play piano and volleyball. I just finished seventh grade, and my favorite subjects are science, math, art, and Spanish. I love to read, particularly Sci-Fi novels and series (I am also a huge fan of Harry Potter). I am very excited to be working with Frontiers for Young Minds!

\section{AUTHORS}

\section{PIERRE GANAULT}

At each walk in nature, I cannot help myself from flipping logs and rocks over or searching into the dead leaves to see what wonderful animal I will find hiding there. This curiosity led me to study soil biodiversity and do a Ph.D. on the effect of tree species mixture on soil invertebrates and the role of these animals for soil processes. I also work with associations to bridge the gap between scientists and citizens so we can work all together to study, better understand, and protect the creatures living in the soil. *pierre.ganaultagmail.com

\section{SACHA DELMOTTE}

My passions for nature, humans, science, and the transmission of knowledge led me to pursue 7 years of university studies in ecology, biology, and geology. I am also an animator in the plains of nature for audiences ranging from 3 to 18 years old to awaken them to the things that fascinate me.

\section{AGNÈS DUHAMET}

Agnès is a Ph.D. student in marine biology. She obtained her bachelor's degree in biology at the University of Avignon and her master's degree in ecology and evolutionary biology at the University of Montpellier. She is passionate about nature and likes to transmit knowledge about natural sciences.

\section{GAËLLE LEXTRAIT}

I have always been passionate about microorganisms, whether pathogenic or mutualistic. I turned to the interactions between small animals living in soils (insects) and their symbionts. I am currently a Ph.D. student in microbiology at the CNRS of Gif-sur-Yvette (University Paris-Saclay), where I am continuing my observations on the symbiotic interactions between stinkbugs and their symbiotic bacteria.

\section{YVAN CAPOWIEZ}

Yvan Capowiez is a Senior Research Scientist at the French Agronomy Institute (INRAE), Avignon, France. His research is focused on earthworm ecology and behavior. He has extensive experience studying how earthworms burrow in the soil and how the resulting burrows will influence important soil functions, such as water transport and organic matter burial. 